\author{
Sharaf N. Rehman \\ University of Texas Rio Grande Valley \\ e-mail: sharaf.rehman@utrgv.edu
}

\title{
Teaching Ethics in an Unethical World
}

\begin{abstract}
We find ourselves in times where national leaders engage in fraudulent and deceptive behaviors for personal and political gains, and multinational corporations use unethical practices to maximize their profits. Where dangerously defective products are released onto the market endangering the health and lives of consumers, and where news channels become opinion channels. Where the motto of the free market is reduced to a simple 'grab all you can, any way you can.' In times such as these, it is difficult to teach and promote ethical behavior. A cursory look at the advertising messages and the spins put on issues by public relations people leaves one wondering if business ethics is anything more than an oxymoron - a self-contradicting claim. In times such as ours (in 2017), it is crucial that institutions of higher learning continue to teach and foster ethical behavior and ethical responsibility. No doubt, it is an uphill struggle for educators to convince students to think and act in ethically appropriate terms when surrounded by corruption, deceit, and fraud. While no one will deny the need for ethical practices, teaching these values in a convincing manner remains a challenge. Using meta-analysis of various University courses in ethics, the present paper attempts three goals. First, it builds a rationale for the importance of ethical behavior, the need for teaching it, and the criticisms of those who think it unnecessary to teach ethics. Second, it discusses various strategies used by universities and several educators in teaching and reinforcing ethical behavior. This section also offers a criticism of approaches and methodologies of teaching ethics. Third, it offers an outline for a syllabus for an introductory course in Ethics.
\end{abstract}

Keywords: moral philosophy; ethical behavior; business ethics; teaching ethics

JEL Classification: A20, I23, M14 
Good people don't need laws to tell them to act responsibly and bad people will find a way around the laws.

Plato

\section{Introduction}

There are times when pointing at the problems is easier than showing the solutions. Ethical conduct is one such case. It is easier to offer examples of unethical conduct than to come up with the solutions for motivating people to refrain from such unethical behaviors. A denotative description may be one possible starting point for gaining an understanding of what ethics is. The American Heritage Dictionary ( $5^{\text {th }}$ ed.) defines it as 'a set of principles of right conduct.' The Concise Oxford English Dictionary states that ethics is 'the science of moral principles or rules of conduct.' Merriam-Webster Dictionary defines ethics as 'the discipline dealing with what is good and bad and with moral duty and obligation.' All three stress the 'right' conduct in terms of moral values. The insistence on right and wrong is also a common thread in all definitions; however, what may be considered right or wrong is open to interpretation and ambiguity.

The word 'ethics' comes from the Greek éthikos, meaning 'of or for morals.' It is for this philological connection that so often the two, ethics and morals, are used interchangeably. This convenience, however, may not serve scientific or objective pursuits. The two are distinctly different. The table below may help make the distinction.

Table 1. Morals vs ethics

\begin{tabular}{|l|l|}
\hline \multicolumn{1}{|c|}{ Morals } & \multicolumn{1}{c|}{ Ethics } \\
\hline Carry a religious connotation & $\begin{array}{l}\text { Deals with reasoning and rationale for hu- } \\
\text { man conduct. It seeks secular objectivity }\end{array}$ \\
\hline Have a notion of external control & Suggests a control from within \\
\hline Are prescriptive & Is (mostly*) descriptive \\
\hline Are concerned with good and evil & Concerns itself with right and wrong \\
\hline Create a sense of obligation & Creates a sense of responsibility \\
\hline
\end{tabular}

* Some aspects of deontological ethics and virtue ethics prescribe specific behaviors.

Just as most people engage in ethnocentrism, by believing that their own customs, language, traditions, and cuisine are better than those of others, one may expect that most people also engage in ethics-centrism - a belief that one's own moral values or ethical principles are superior to those of others. It may be difficult to pinpoint ethics, yet, it is inescapable.

It would be hard to imagine a society in which there are no codes of conduct and people are free to do absolutely as they please; a society without rules, laws, morals, or social responsibility. Historians would be quick to remind us that the demise of great civilizations and empires occurred due to a gradual decaying of morals and ethical standards. Those nations didn't fail; their institutions collapsed as the people in them abandoned their ethics and morals. 


\section{Ethics and philosophy}

What follows is a brief description of various branches of ethics. Moral philosophy is the branch of philosophy that explores what is right and wrong; how people ought to live their lives. ${ }^{1}$ It is divided into three areas: Meta-Ethics, Normative Ethics, and Applied Ethics. Meta-Ethics is the most abstract area of moral philosophy. It deals with the big question: What is morality? ${ }^{2}$ Normative Ethics provides a moral framework that may help people determine which actions are good and bad, right and wrong. ${ }^{3}$ There are three main schools in Normative Ethics: Virtue Ethics, ${ }^{4}$ Deontology, ${ }^{5}$ and Teleological Ethics, or Consequentialism. ${ }^{6}$ Applied ethics is the most down to earth and practical aspect of moral philosophy. ${ }^{7}$ It helps people tackle sensitive ethical issues: e.g. abortion, animal rights, justice, human rights, and capital punishment.

David Hume saw moral philosophy as a two-sided coin; one side dealing with questions regarding how people ought to live their lives (Evaluative Ethics), and the other side addressing how people actually live their lives (Descriptive Ethics), and that one couldn't simply walk from one to the other. ${ }^{8}$

From Plato and Aristotle to Emmanuel Kant, some of the greatest minds have argued for an absolute position on morality, claiming that notions of good and evil, right and wrong, equality and partiality are universal, and must be followed regardless of the situation. In other words, just as there are universal rules in physics, there are absolute rules for ethical and moral conduct, i.e., the rightness or wrongness of actions does not depend on their consequences but on whether they fulfill our duty. Kant's Categorical Imperative is absolutely binding and prescriptive; it dictates that it is one's duty to do the right thing, thus, if $\mathrm{X}$ is the right thing to do, one must always do $\mathrm{X} .{ }^{9}$ No ifs or buts.

An alternative to Kantian Absolutism is Ethical Relativism, ${ }^{10}$ denoting that what is morally right or wrong depends on the norms of a given culture at a given point in time. Therefore, there is no universal moral code by which all people live. The rules for evaluating right and wrong, good and evil, just and unjust, may change according to the circumstance. A conduct that was unacceptable at one time may become acceptable in a different time or in a different place. Laws are made by people; laws change.

\footnotetext{
${ }^{1}$ R.L. Holms, Basic Moral Philosophy, 4 ${ }^{\text {th }}$ ed., Wadsworth Cengage Learning, Belmont, CA 2007.

${ }^{2}$ H.J. McCloskey, Meta-Ethics and Normative Ethics, Marinus Nijhoff, The Hague 1969, p. 2.

${ }^{3}$ Ibidem, p. 3.

${ }^{4}$ Plato, The Republic, Penguin Press, Harmondsworth, Middlesex 1955 [C. 380 BCE].

${ }^{5}$ I. Kant, Fundamental Principles of the Metaphysics of Morals, Tr. Thomas Kingsmill Abbott, Mineola, N.Y. 2005 [1786].

${ }^{6}$ G.E.M. Anscombe, Modern Moral Philosophy, "Philosophy” 1958, Vol. 44, No. 124, pp. 1-19; P.K. Moser, Th.L. Carson, Moral Relativism: A Reader, Oxford University Press, New York 2000.

${ }^{7}$ J. Rachels, The Elements of Moral Philosophy, $8^{\text {th }}$ ed., McGraw-Hill, Boston 2014.

${ }^{8}$ D. Hume, A treatise of human nature, eds. D.F. Norton, M.J. Norton, Oxford University Press, Oxford 2000 [1739-1740].

9 J. Mizzoni, Ethics: The Basics, Wiley, Hoboken 2017.

${ }^{10}$ R. Shafer-Landau, The Fundamentals of Ethics, Oxford University Press, New York 2017.
} 
The Normative Ethical theory, captured in Ovid's exitus acta probat (the end justifies the means), proposes that if a goal is morally important, any method to achieve it is acceptable. ${ }^{11}$ Consequentialism argues that the end result of one's actions is the touchstone for judging the rightness or wrongness of those actions. Thus, from a consequentialist standpoint, an action that renders a good outcome is the right action (or non-action). Indeed, such consequentialism or relativism suits the corporate world much better than the universally binding rules of Kantian Absolutism and the Categorical Imperative. In its place, the relativist prefers a Hypothetical Imperative: Do A to achieve X. In so doing, one has to be absolutely certain that $\mathrm{X}$ is a legitimate goal, and doing $\mathrm{A}$ will produce $\mathrm{X}$. With the limitations of human knowledge and uncontrollable variables, the two conditions are seldom satisfied.

\section{Ethics and business}

Since people's morals are rooted in their beliefs, moral philosophy evaluates the rights and wrongs in terms of belief systems. This is not limited to religious beliefs only, as non-religious people also operate under their self-imposed values and codes of ethics. Fundamentally, it is these codes of ethics that steer the social systems guiding people on how to interact, rely on others, support others, and expect others to abide by the agreed upon rules. In any given culture, the fundamental rights and rules are for all of its members. Societal rules define an individual's responsibility to the society and require that an individual's actions should benefit the society and not just the individual, and that one should be fair to others. One may ask who is to decide on obligation, and how much obligation? How much benefit to how large a segment of a society? Is it possible to be equally fair to all members of a society?

Social systems also grant two types of rights to their publics - legal rights and natural rights. Legal rights are determined by humans. These are the set of laws that give people their privileges and responsibilities in a specific society, e.g. the right to take part in the political process, the right to access formal education, or the right to freely practice a chosen religion. Laws can change; legal rights can change. Natural rights, moral philosophers hold, are the rights that every human has at birth. For instance, the right to express one's opinion, freedom of thought regarding religion and beliefs, and the right to one's privacy are considered universal rights and principles. Some believe that these rights are granted by a higher power; others hold that these rights are an innate part of being a human.

In recent decades, corporate greed has taken the notions of relativism and consequentialism to new unethical. Without a doubt, the mission of multinational corporations is to maximize the return on investment (the end), therefore, all actions leading to greater profits (the means) are justifiable - a convenient case for consequentialism. Such an approach benefits the 100 richest corporations and their shareholders, but it is not in the best interest of the majority of the people on this planet.

${ }^{11}$ B. Russell, A History of Western Philosophy, Simon \& Schuster, New York 1967 [1945]. 
During the tsunami of deregulations in the 1980s, the mergers and acquisitions, stock prices fluctuated in an unparalleled manner. Stock prices rose on rumors of takeovers. Those with access to such information before it became public gained immensely. In the 1992 book Den of Thieves, James Stewart chronicles the insider trading by Ivan Boesky, Michael Milken, and other Wall Street financiers who accumulated millions of dollars by defrauding investors. Among the dozens of people named in the book, Michael Milken was indicted for racketeering, securities fraud, and insider trading, fined $\$ 600$ million, and made to pay $\$ 500$ million to the investors, and legal fees. ${ }^{12}$ He was sent to prison for ten years. He served only 22 months. On his release, he made millions more by embarking on a lecture tour. During the last four years of his tenure at Drexel Burnham Lambert, Milken's compensations exceeded \$1 billion. His estimated net worth in 2017 is \$3.6 billion.

Using a consequentialist argument in an American movie (Wall Street, 1987; Director, Oliver Stone), as he addresses his stockholders, a CEO, Gordon Gekko (Michael Douglas) sums up his philosophy on greed and ethics by claiming that greed has made his company profitable and greed is what will save the USA. ${ }^{13}$ In contrast to the fictitious and make-believe values of Hollywood, President Obama and nearly all of the Members of Congress, while discussing the $\$ 1$ trillion bailout of the U.S. banks, insurance companies, and the auto industry, blamed the crisis on the 'greed and irresponsibility of Wall Street'. ${ }^{14}$

\section{Ethics and academe}

Surprisingly, there are people that neither believe in teaching ethics, nor consider it necessary for conducting business and making a profit. Milton Friedman, in his famous article The Social Responsibility of Business Is to Increase Its Profits, arguing for 'business first', wrote: 'There is one and only one social responsibility of business - to use its resources and engage in activities designed to increase its profits ${ }^{\prime 15}$ As an afterthought, Friedman recommended that a business should engage in open and free competition without deception or fraud.

Peter Drucker held that profitability and responsibility were compatible notions and a business should convert social responsibilities into business opportunities. ${ }^{16} \mathrm{He}$ advocated that business people should not have to subscribe to the same set of ethics that apply to or-

\footnotetext{
12 J.B. Stewart, Den of Thieves, Simon \& Schuster, New York 1992.

${ }^{13}$ Gordon Gekko's speech on greed: 'The point is, ladies and gentleman, that greed, for lack of a better word, is good. Greed is right, greed works. Greed clarifies, cuts through, and captures the essence of the evolutionary spirit. Greed, in all of its forms; greed for life, for money, for love, knowledge has marked the upward surge of mankind. And greed, you mark my words, will not only save Teldar Paper, but that other malfunctioning corporation called the USA.' (Screenplay by Oliver Stone \& Stanley Weiser).

${ }^{14}$ R.A. Giacalone, D. Wargo, The Roots of the Global Financial Crisis Are in Our Business Schools, "Journal of Business Ethics Education” 2009, Vol. 6, p. 147, doi: 10.5840/jbee200969.

${ }^{15}$ M. Friedman, The Social Responsibility of Business Is to Increase Its Profits, "The New York Times Magazine" 1970 , September $13^{\text {th }}$, emphasis added.

${ }^{16}$ P.F. Drucker, The new meaning of corporate social responsibility, "California Management Review" 1984 , Vol. 26, p. 62.
} 
dinary people. Ethics, he claimed, chains people and their activities. According to Drucker, a company's primary responsibility is to serve its customers; profit is not the primary goal, but an essential condition for the company's continued existence and sustainability. Others have argued that ethics courses fail to teach students how to improve society under the disarrayed and chaotic conditions of the world, and that the courses only induce passive moral thinking rather than moral action. Piper, Gentile \& Parks (1990) chronicled the Harvard University's efforts of teaching ethics. ${ }^{17}$ Hummel, Pfaff \& Rost concluded that university education, in general, did not foster moral development. ${ }^{18}$ Add to this, the developmental psychology theories suggesting that an individual's personality is defined by the age of five..$^{19}$ The average age of a Harvard MBA student is 27; is it too late to start trying to instill a sense of ethics at that stage? One institution that takes this view is Berkeley's Haas School, which claims that the best strategy is to admit applicants who are not only smart, accomplished, and ambitious but who also reflect the solid ethical values of the program.

Does this mean that people cannot be changed after the age of five? Evidence shows that people do change. People acquire new opinions, develop new attitudes, and modify their behaviors. Critics of business education hold that there is something wrong with the business people who are products of our business schools. ${ }^{20}$ Citing several studies that have shown the 'deleterious effects of business schools on student values and behavior', Pfeffer believes that business school training, the profit-driven economic thinking, and the business school environment are the sources of this problem. ${ }^{21}$ Giacalone and Wargo have plainly labeled it as 'toxic teaching' in our business schools. ${ }^{22} \mathrm{McC}$ abe and Treviño have focused much of their academic research on ethical behavior by students, and by individuals in business organizations. They have found significantly higher levels of cheating among undergraduate business students than among other students. ${ }^{23}$ In their most recent study, with 5000 graduate students at 32 universities, they found that more than half $(56 \%)$ of graduate business students - mostly MBA students - admitted to having cheated at least once in the past academic year. Only $47 \%$ of their non-business school peers admitted to cheating. ${ }^{24}$ A content analysis of ethics syllabi showed that nearly $53 \%$ of the syllabi also included statements about academic honesty. ${ }^{25}$

\footnotetext{
${ }^{17}$ Th.R. Piper, M.C. Gentile, Sh.D. Parks, Can Ethics Be Taught? Perspectives, Challenges, and Approaches at Harvard Business School, Harvard Business School Press, Boston, MA 1990.

${ }^{18}$ K. Hummel, D. Pfaff, K. Rost, Does Economics and Business Education Wash Away Moral Judgment Competence?, "Journal of Business Ethics" 2016, doi: 10.1007/s10551-016-3142-6.

${ }^{19}$ E. Erikson, Childhood and Society, W.W. Norton \& Company, New York 1950; R.H. Shute, P.T. Slee, Child Development: Theories and Critical Perspectives, Routledge, New York 2015.

${ }^{20}$ MBA students: Not all bad. Despite the negative press, many MBA students remain a force for good, "The Economist" 2009, June 29 $9^{\text {th }}$ http://www.economist.com/node/13892606 (accessed in December 2017).

${ }^{21}$ J. Pfeffer, Why Do Bad Management Theories Persist? A Comment on Ghoshel, "Academy of Management Learning and Education" 2005, Vol. 4, No. 1, pp. 96-100.

22 R.A. Giacalone, D. Wargo, op. cit., p. 151.

${ }^{23}$ D.L. McCabe, L.K. Treviño, Cheating among business students: A challenge for business leaders and educators, "Journal of Management Education" 1995, Vol. 19, pp. 205-218.

${ }^{24}$ D.L. McCabe, K. Butterfield, L. Treviño, Academic Dishonesty in Graduate Business Programs: Prevalence, Causes, and Proposed Action, "Academy of Management Learning \& Education” 2006, Vol. 5, No. 3, pp. 294-305.

${ }^{25}$ S.M. Grifith, D. Rodriguez, M. Melanie, A.J. Anderson, Graduate Ethics Education: A Content Analysis of Syllabi (2014), "Psychology Faculty Publications" 2014, Paper 1081, http://digitalcommons.usu.edu/psych_facpub/1081.
} 
Michael Milken graduated from the Wharton School of Business. Ivan Boesky graduated from Michigan State University, College of Law. Jeffery Skilling, former CEO of Enron, graduated from Harvard School of Business, as did Obed Aboodi, Ester Reed, Eugene Plotkin, and Andre Shliefer. All of these Harvard graduates went to prison for unethical \& criminal conduct. Rajat Gupta, a former Managing Director of McKinsey, was also sent to prison for insider trading in 2014. John Thain, former CEO of Merrill Lynch, who avoided prison but resigned from his position in disgrace, was also a Harvard graduate. ${ }^{26}$

Mathew Martoma, who graduated with a degree in biomedicine, ethics, and public policy from Duke University in 1995, went to Harvard Law School in 1997 and was expelled from there in 1999 for having forged his transcripts. In 2001, he managed to get into Stanford University and graduated with an MBA in 2003. Martoma was convicted and sent to prison for fraud and insider trading in 2014. Stanford University's response: It rescinded Martoma's degree claiming he falsified his credential on his application. ${ }^{27}$

In the wake of the Milken and Boesky episode, and hundreds of other similar instances, many universities rushed to revise their curricula to incorporate training in ethics and morality. However, the news media have challenged and questioned the ethical content in business, accounting, and law programs. A New York Times article titled, 'Is it Time to Retrain B-Schools?' charged:

Some say the schools have become too scientific, too detached from real-world issues. Others say students are taught to come up with hasty solutions to complicated problems...that schools give students a distorted view of their role... as the agents of the owners - the shareholders - and responsible for maximizing shareholder wealth. ${ }^{28}$

Questioning the behavior of business students, an Aspen Institute report's title speaks volumes: Where Will They Lead? MBA Student Attitudes about Business and Society. ${ }^{29}$

A Wall Street Journal article, titled Promises Aren't Enough: Business Schools Need to Do a Better Job Teaching Students Values, stated: 'Business education is much more scientific than it was in its early years. It has been made more rigorous by the rising influence of statistics and economics. We believe in analytics. Most organizations need more analytics. But analytics are not a substitute for values'. ${ }^{30}$ There is neither a substitute for analytics nor for ethics. Our students and decision-makers need both.

\footnotetext{
${ }^{26}$ D. McKissen, Harvard MBAs Keep Going to Prison. So why do They Still Rule the World?, 2016, December $30^{\text {th }}$, https://www.inc.com/dustin-mckissen/harvard-mbas-keep-going-to-prison-so-why-do-they-still-rul e-the-world-.html (accessed on June $8^{\text {th }}, 2017$ ).

${ }^{27}$ S. Perlberg, Former SAC Trader Mathew Martoma Just Lost His Stanford MBA, "Business Insider" 2014, March 5, http://www.businessinsider.com/mathew-martoma-loses-stanford-mba-2014-3?IR=T (accessed on June $\left.9^{\text {th }}, 2017\right)$.

${ }^{28}$ K. Holland, Is It Time to Retrain B-Schools?, "New York Times" 2009, $15^{\text {th }}$ March.

${ }^{29}$ Aspen Institute, Where Will They Lead? MBA Student Attitudes about Business and Society, Aspen Institute for Social Innovation through Business, New York 2001.

${ }^{30}$ R. Canales, C. Massey, A. Wrzesniewski, Promises Aren't Enough: Business Schools Need to Do a Better Job Teaching Students Values, "Wall Street Journal” 2010, August $23^{\text {rd }}$.
} 


\section{Teaching ethics}

There are three streams of courses in ethics.

(1) The business programs focus on training managers/leaders to make ethical decision in solving problems.

(2) The engineering and the sciences programs stress ethical issues in scientific research, objectivity, intellectual property, and plagiarism. The business schools, the sciences programs, and the law schools approach ethics from a normative or consequentialist perspective. The focus of these discipline-specific courses in ethics is too narrow. There is more to ethics than business decisions, conflicts of interest, legal issues, intellectual property, and plagiarism. All aspects of human conduct are a concern for ethics. To say that topics A, B, and C are not relevant to doctors and nurses, or that issues $\mathrm{K}$, $\mathrm{L}$ and $\mathrm{M}$ are not applicable to lawyers or economists, is going to lead to providing an incomplete treatment of ethics.

(3) The ethics courses in humanities often provide a broader coverage and are generally critical of big businesses and lack of business ethics. These courses approach the subject from the evaluative (deontological) perspective. Many Liberal Arts programs either offer stand-alone courses in ethics, or incorporate it in their courses across the core curriculum.

Teaching across the curriculum is a practice that has been applied to teaching Public Speaking, Critical Thinking, and College Writing. Such an approach implies that all courses will incorporate writing, speaking, critical thinking, and ethics. In plainer language, it means that math teachers will incorporate writing, public speaking, critical thinking, and ethics in their courses. History professors will do the same, and so will sociology teachers, world literature teachers, and philosophy teachers. Something is basically wrong with this approach. It requires that faculty in all disciplines must include writing, public speaking, critical thinking, and ethics in their syllabi. Most of the faculty members are not trained to teach in all of these areas. Many of them may have never taken a course in critical thinking, ethics, or public speaking. Several universities, MIT and the Univ. of Montana, among them, offer online courses that are free and open to anyone and everyone. ${ }^{31}$

McDonald \& Donleavy view the ethics courses as a means of achieving ethical awareness and sensitivity. ${ }^{32}$ The universities understand and admit that ethics courses may not make the students more ethical; however, these courses may help the learners to identify and analyze ethical issues in real life and at work. Hodhod, Kudenko, and Cairns argue that games can be used to teach ethics to young adults and teens. ${ }^{33}$ Staaby has used video games to teach ethics to high school students. Many of the games incorporated in col-

\footnotetext{
${ }^{31}$ M.V. Harrington, R.D. Walsh, BGEN 320E.01: Business Ethics and Social Responsibility, University of Montana Syllabi 2015, Paper \# 2574, http://scholarworks.umt.edu/syllabi/2574 (accessed in December 2017).

32 G.M. McDonald, G.D. Donleavy, Objections to the Teaching of Business Ethics, "Journal of Business Ethics" 1995, Vol. 14, pp. 839-853, doi:10.1007/BF00872350.

${ }^{33}$ R. Hodhod, D. Kudenko, P. Cairns, Serious Games to Teach Ethics, "Proceedings of AISB” 2009, Vol. 9, pp. 6-9.
} 
lege courses in economics (Prisoners Dilemma, Lost Money, and Ultimatum) compel the learners to become more analytical, and to make and evaluate their personal decisions in light of morals and ethics. ${ }^{34}$

There is an ongoing debate as to who should be teaching ethics. Since not every university or professional studies program has its own philosopher or ethicist, many law and business programs have lawyers and accountants teach these courses. In the humanities, faculties in philosophy, psychology, sociology, and political sciences teach these courses. Perhaps therein lies the problem - people that are not formally trained in ethics are teaching it. In addition to this practical concern, there is also a moral dilemma in teaching ethics. Whose ethics and morality are the teachers going to teach? Obviously, their own; their own values and views that may have been tainted by their own religious and cultural beliefs. What right does one individual have to impose his or her ethics on another person? As a teacher, one has neither the right to change the students' behaviors nor to challenge or change their beliefs.

This author argues for ethics courses to be 'required', not optional. Optional implies that one may take it or leave it; that it is not seen as important. Such a stance equates to saying that people may act ethically if they so choose, but they are not required to act ethically. The goal of teaching ethics is to provide the learners the skills and tools to analyze a given situation, to evaluate the appropriateness or inappropriateness of each alternative solution, and to make the best choices. These are matters of great importance and shouldn't be treated casually. It is absurd to think that doing the right thing is optional.

It may be true that those disposed to unethical behavior will not only resort to unethical behavior but may also avoid taking courses in ethics. The optimistic position to take is to assume that most people are not 'bad apples', only a few are. Those that opt to take courses in ethics are more likely to act ethically and morally. For them, courses in ethics not only reinforce their moral values and attitudes, but sharpen their logical reasoning skills and rational decision making.

\section{Conclusion}

In teaching a college-level course in ethics, an utterly objective position must be taken to present as many of the different theories as possible, and to provide the learners with the skills for analysis, reasoning, and the acquisition of knowledge. This requires shedding one's ethnocentrism, ethics-centrism, and personal biases. There exist some absolutes with definite rights and wrongs, there are just as many, if not more, that fall somewhere in between. There's more gray area in our globalized world than black and white. A course in ethics would remain incomplete without a discussion of abstract ideas such as equality in regards to race, color, gender, and religion, and equity, e.g., equal pay for equal work, individual rights, justice, and the concept of freedom in regards to thoughts and conduct.

\footnotetext{
${ }^{34}$ P. Darvasi, Literature, Ethics, Physics: It's All In Video Games At This Norwegian School, KQED News, Mind/Shift. How We Will Learn 2014, July 21 $1^{\text {st }}$, https://ww2.kqed.org/mindshift/2014/07/21/literature-ethics-physics-its-all-in-video-games-at-this-norwegian-school/ (accessed in December 2017).
} 
Yes, the jury is still out on how effective it is to teach ethics, however, no one is suggesting that we stop trying. What may happen if we abandon ethics and ethical behavior? Knowing that despite our efforts in teaching our children to always tell the truth, not to cheat, steal, or hurt others, some of our children will grow up to be liars, cheats, criminals, and crooks, we continue to reinforce ethical values in our children. We should continue this work in elementary schools, high schools, and post-secondary education. Yes, at times, it may seem to be a losing battle, yet we can't stop the battle against unethical practices. The alternative: Not teaching ethics is unimaginable, unacceptable, and unethical.

\section{References}

Anscombe G.E.M., Modern Moral Philosophy, "Philosophy" 1958, Vol. 44, No. 124, pp. 1-19.

Aspen Institute, Where Will They Lead? MBA Student Attitudes About Business and Society, Aspen Institute for Social Innovation Through Business, New York 2001.

Canales R., C. Massey, A. Wrzesniewski, Promises Aren't Enough: Business Schools Need to Do a Better Job Teaching Students Values, "Wall Street Journal” 2010, August $23^{\text {rd }}$.

Darvasi P., Literature, Ethics, Physics: It's All In Video Games At This Norwegian School, KQED News, Mind/Shift. How We Will Learn 2014, July 21 ${ }^{\text {st }}$, https://ww2.kqed.org/mindshift/2014/07/21/literature-ethics-physics-its-all-in-video-games-at-this-norwegian-school/.

Drucker P.F., The new meaning of corporate social responsibility, "California Management Review" 1984, Vol. 26, pp. 53-63.

Erikson E., Childhood and Society, W.W. Norton \& Company, New York 1950.

Friedman M., The Social Responsibility of Business Is to Increase Its Profits, “The New York Times Magazine" 1970, September $13^{\text {th }}$.

Giacalone, R.A., D. Wargo, The Roots of the Global Financial Crisis Are in Our Business Schools, "Journal of Business Ethics Education" 2009, Vol. 6, pp. 147-168, doi: 10.5840/jbee200969.

Grifith S.M., D. Rodriguez, M. Melanie, A.J. Anderson, Graduate Ethics Education: A Content Analysis of Syllabi, "Psychology Faculty Publications" 2014, Paper 1081, http://digitalcommons.usu.edu/psych_facpub/1081.

Harrington M.V., R.D. Walsh, BGEN 320E.01: Business Ethics and Social Responsibility, University of Montana Syllabi 2015, Paper \# 2574, http://scholarworks.umt.edu/syllabi/2574.

Hodhod R., D. Kudenko, P. Cairns, Serious Games to Teach Ethics, "Proceedings of AISB" 2009, Vol. 9, pp. 6-9.

Holland K., Is It Time to Retrain B-Schools?, "New York Times" 2009, March 15"t .

Holms R.L., Basic Moral Philosophy, 4 ${ }^{\text {th }}$ ed., Wadsworth Cengage Learning, Belmont, CA 2007.

Hume D., A treatise of human nature, eds. D.F. Norton, M.J. Norton, Oxford University Press, Oxford 2000 [1739-1740].

Hummel K., D. Pfaff, K. Rost, Does Economics and Business Education Wash Away Moral Judgment Competence?, "Journal of Business Ethics" 2016, doi: 10.1007/s10551-016-3142-6.

Kant I., Fundamental Principles of the Metaphysics of Morals, Tr. Thomas Kingsmill Abbott, Mineola, N.Y. 2005 [1786].

MBA students: Not all bad. Despite the negative press, many MBA students remain a force for good, "The Economist" 2009, June 29 $9^{\text {th }}$, http://www.economist.com/node/13892606. 
McCabe D.L., K. Butterfield, L. Treviño, Academic Dishonesty in Graduate Business Programs: Prevalence, Causes, and Proposed Action, "Academy of Management Learning \& Education" 2006, Vol. 5, No. 3, pp. 294-305.

McCabe D.L., L.K. Treviño, Cheating among business students: A challenge for business leaders and educators, "Journal of Management Education" 1995, Vol. 19, pp. 205-218.

McCloskey H.J., Meta-Ethics and Normative Ethics, Marinus Nijhoff, The Hague 1969.

McDonald G.M., G.D. Donleavy, Objections to the Teaching of Business Ethics, "Journal of Business Ethics"1995, Vol. 14, pp. 839-853, doi:10.1007/BF00872350.

McKissen D., Harvard MBAs Keep Going to Prison. So why do They Still Rule the World?, 2016, December 30, https://www.inc.com/dustin-mckissen/harvard-mbas-keep-going-to-prison-so -why-do-they-still-rule-the-world-.html.

Mizzoni J., Ethics: The Basics, Wiley, Hoboken 2017.

Moser P.K., Th.L. Carson, Moral Relativism: A Reader, Oxford University Press, New York 2000.

Perlberg S., Former SAC Trader Mathew Martoma Just Lost His Stanford MBA, "Business Insider" 2014, March $5^{\text {th }}$, http://www.businessinsider.com/mathew-martoma-loses-stanford-mba-2014-3? IR $=\mathrm{T}$.

Pfeffer J., Why Do Bad Management Theories Persist? A Comment on Ghoshel, "Academy of Management Learning and Education" 2005, Vol. 4, No. 1, pp. 96-100.

Piper Th.R., M.C. Gentile, Sh.D. Parks, Can Ethics Be Taught? Perspectives, Challenges, and Approaches at Harvard Business School, Harvard Business School Press, Boston, MA 1990.

Plato, The Republic, Penguin Press, Harmondsworth, Middlesex 1955 [C. 380 BCE].

Rachels J., The Elements of Moral Philosophy, $8^{\text {th }}$ ed., McGraw-Hill, Boston 2014.

Russell B., A History of Western Philosophy, Simon \& Schuster, New York 1967.

Shafer-Landau R., The Fundamentals of Ethics, Oxford University Press, New York 2017.

Shute R.H., P.T. Slee, Child Development: Theories and Critical Perspectives, Routledge, New York 2015.

Stewart J.B., Den of Thieves, Simon \& Schuster, New York 1992.

\section{APPENDIX I}

\section{Introduction to Ethics}

\section{Goals:}

(1) Become familiar with philosophical theories on moral judgments and integrate them in everyday decision-making.

(2) Develop the skills to evaluate the choices in making ethical judgments in personal life and in business.

Course Description: This course will serve as an introduction to philosophy through a discussion of actions and choices that may be right or wrong. Using the Socratic Method and discussion, the course will examine the nature of morality and moral values by asking questions such as: 
What are we doing when we say that an action is wrong? Are we offering our personal opinion or are we making an objective claim about a specific action? Or, are we simply expressing a negative emotional reaction?

We will ask what makes actions right or wrong. Is it because it's our duty to perform the action, or is it because we think an action will lead to the right consequences?

What if performing a duty results in bad consequences for some? Who decided what the duty is? Should one challenge the duty if performing it will result in immoral consequences? Can a duty or a law be unethical?

We will consider the different views of rightness or wrongness of actions to guide us on a number of contemporary moral issues, such as capital punishment and abortion. Is it wrong to eat meat? What should the society do with people who commit horrific crimes? Is abortion morally permissible? Who should be held responsible for juvenile delinquency? Is it ethical to hunt and kill animals as a sport? What are the rights of a patient? What is the right action for a medical professional in regard to a terminally ill patient suffering with unbearable pain and discomfort? Is assisted suicide immoral and unethical? How do we determine 'fair and reasonable' profit? Are predatory pricing (selling at a very low price to eliminate the competition) and exploitative pricing (charging a very high price) ethical? Should price collusion by the pharmaceutical companies, the agriculture industry, gas companies, airlines, and the food industry be permissible? Are such practices for the benefit of the majority of people or large corporations?

This course will also explore ethical debates in scientific fields, such as misconduct in research, conflicts of interest, scientific objectivity, intellectual property, and plagiarism.

Lectures, readings, and group projects will include:

(1) Classical theories of Ethics such as

Virtue Ethics (Plato and Aristotle),

Deontology (Immanuel Kant)

and Utilitarianism (David Hume, John Stuart Mill).

(2) Contemporary schools of thought

- Social Contract theory (Thomas Hobbes, John Locke, and Jean-Jacques Rousseau),

Distributive Justice Theory (Equity, Equality, Power, Need, Responsibility),

Moral Subjectivism and Relativism. 